\title{
Corporate Expectations and Students Skills - Gap Analysis in Career Carver Group -Baramati
}

\author{
Mrs Nikita Sarthak Patil
}

\section{Organised By:}

Management Department, Chhatrapati Shahu Institute of Business Education and Research, Kolhapur, Maharashtra

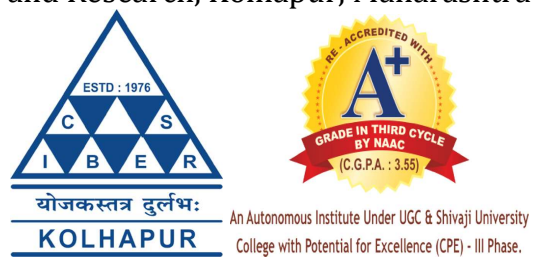

How to cite this paper: Mrs Nikita Sarthak Patil "Corporate Expectations and Students Skills - Gap Analysis in Career Carver Group -Baramati" Published in International Journal of Trend in Scientific Research and Development (ijtsrd), ISSN: 2456-6470, Special Issue | Fostering Innovation, Integration and Inclusion Through Interdisciplinary

Practices in Management, March 2019, pp.46-48, URL: https://www.ijtsrd.c om/papers/ijtsrd23 061.pdf

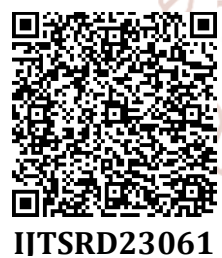

\section{COMPANY PROFILE}

In expanding global markets, technology based innovation is the most important driver of growth. We have been building world class training centre \& placement cell for minimize gap between corporate $\&$ employee.

The company was set up in August 2016, with vision to give best solution to students, businessperson and a common person society. The objective of company is to train students for make a bright career, to train businessperson for great success and to train a common person to live a happy life.

Institution Training \& Development centre.

Founded Aug 2016

Headquarter Baramati Dist - Pune.

Director Miss, Padmini chavan (Director)

Modules Career Counseling, Training and Development, Placement, Corporate Training, their soft skills. suggestion.

\section{INTRODUCTION TO STUDY}

A corporate skill means talent of staff or skills, or interpersonal way of doing ings." In today's world, most of the people have knowledge but what really differentiates them from others is the way they represents themselves by using

A corporate skill improves interaction within the organization at different level. In day to day corporate work culture, working style etc., depend on how you communicate with your network.

"Degree \& credentials are important, but the developments of corporate skillsskills that are more social than technical- are a crucial part of fostering a dynamic workforce and are always in high demand" (According to Myers) From the above Myers, focused that, these corporate skills are interpersonal skills, that develops

Corporate skills is a comprehensive term including various skills project management skills, problem solving skills, time management, communication skills, computer \& technical skills, adaptability etc. In the corporate world, you ed to have both effective oral as well as written communication skills. If you are for promotion, you should be an effective speaker maintaining good eye

\section{OBJECTIVES OF STUDY}

$>$ To recognize corporate expected skills.

$>$ To recognize skills of the students .

$>$ To analyze gap between students skills \& corporate expected skills.

$>$ To give suggestions.

\section{Methodology}

This study firstly proposes to identify the corporate skills required by company towards candidates. And secondly analyze the gap between corporate expected skills and students skills set at work place with using descriptive methodology. The study was done in two parts,

A. Survey Method.

B. Interview Method.

1. Universe of the study-

The universe consist 50 degree holder students come for training and placement.

2. Data collection and statistical tools to be used - 
International Journal of Trend in Scientific Research and Development (IJTSRD) @ www.ijtsrd.com eISSN: 2456-6470

\section{Primary Data:}

Data collected by a researcher is known as primary data. It is collected by a person for his own use obtained from findings. This is considered as first hand information. This is that data which is collected by us to meet our own specific purpose. The data is collected by the means discussion, survey with the candidates at different stream. Data collected from survey, interview with managers, employees, .

\section{Secondary Data:-}

Secondary data means that are already available i.e, they refer to data which has already been collected and analyzed by someone else. This type of data information can also be used by the researcher for his use a s second hand information sources through which secondary data can be collected. Researcher has used following sources of secondary data for this Research

$>$ Company websites.

$>$ Enquiry Reports and company register

\section{Data analysis and interpretation; -}

The collected data is coded saturated and analyzed with the help of necessary statistical methods diagrams and graphs.

Table No 1. Table showing Average of Corporate Expected skills and candidates actual skills

\begin{tabular}{|c|c|c|c|c|}
\hline Sr. No & Skills & Candidates Actual & Corporate Expected & Gap \\
\hline & & Average skills & Average skills & \\
\hline 1 & Verbal skills & 3.16 & 4.4 & 1.24 \\
\hline 2 & Written skills & 3.38 & 4.5 & 1.12 \\
\hline 3 & Interview skills & 3.16 & 4.3 & 1.14 \\
\hline 4 & Behavioral skills & 3.3 & 3.8 & 0.5 \\
\hline 5 & Computer skills & 3.44 & 4.6 & 1.16 \\
\hline & Total & 16.44 & 21.6 & 5.16 \\
\hline & Average & 3.28 & 4.32 & 1.04 \\
\hline
\end{tabular}

Sources: Primary Data

From the above table, on total analysis of skills it can be observed that the actual average skills found in candidates is lower by 1.04 on an average $(4.32-3.28)$ Thus the candidates are required to be more attentive in enhancement of their skills as per the requirement of corporate.

Table No. 2 Table showing Ranking of Skills required by Corporate

\begin{tabular}{|c|c|c|c|}
\hline Sr. No & Skills & Candidates Actual skills average rating & Ranking \\
\hline 1 & Verbal skills & of Trend in Sci3.16 fic & 3 \\
\hline 2 & Written skills & 3.38 & 2 \\
\hline 3 & Interview skills & 3.16 & 3 \\
\hline 4 & Behavioral skills & 3.3 & 4 \\
\hline 5 & Computer skills & 3.44 & 1 \\
\hline \multicolumn{2}{|c|}{ Sources: Secondary Data }
\end{tabular}

Sources: Secondary Data

Above table is showing ranking of skills required by corporate. The first rank goes to the computer skills, which is an essential and mandatory in corporate world. Then the behavioral skills get the second rank. The third rank by verbal and interview skills, last one but written skills.

\section{FINDINGS}

This chapter is based on the objectives of the study, after analysis\& interpretation of the data collected through survey and interview. The following findings are obtained.

$>$ CORPORATE EXPECTED SKILLS

On survey it has been observed that the corporate sector expects the total skills on an average 4.32 on 5 rater scale. Computer skills are highly required for industry and similarly written skills also important. Secondly verbal skills and interview skills also necessary

\section{$>$ CANDIDATES ACTUAL SKILLS}

On survey it has been observed that the candidate's actual skills on an average 3.28 on 5 rater scale. Candidates must have to reach the corporate expected skills. Candidates has been more focus on every skills i.e. verbal, written, interview, behavioral, computer skills.

GAP ANALYSIS

On survey it has been observed that the there has been gap between corporate expected skills and students actual skills. This gap is 1.04 .

\section{Suggestions: -}

On the bases of foregoing study, undertaken analysis and interpretation of data the following suggestions are made to the concern parties.

\section{Suggestions to company:-}

$>$ Company should give attention to improve all the skills sets. Particularly to behavioral skills .

$>$ Company should highlighted more upon the trainings program and trainings modules' to minimize the gap between expected and actual

\section{Suggestions to candidates:-}

$>$ Candidates should improve their skills required by the corporate as there has been major gap between skills expected by corporate and student actual skills sets.

$>$ The candidates should determine their goal in advance and for its fulfillment, an every attempt must be made by them with the guidance and co-operation from concern trainers, higher authorities, and experts. 
International Journal of Trend in Scientific Research and Development (IJTSRD) @ www.ijtsrd.com eISSN: 2456-6470

\section{Suggestions to Institutes:-}

$>$ The education institutes imparting knowledge and skills ought to highlights more upon corporate expected skills development program by establishing the linkages with industry.

$>$ The institutes should be aware of providing guidance to the candidates for grabbing The job oppournities in corporate sector and timely follow off up needed to maintains, retention and development of skills.

Besides regular and theoretical lecture the more practical oriented skills are required to be given to the candidates at frequent intervals of weekly or fortnightly.

\section{CONCLUSION}

It has been well recognized that there has been a wide gap between corporate required skills and candidates actual skills. to minimize such gap, it is at most important that the concern parties should give more emphasis on the skills development for achievement of effective, efficient, productive, and overall balance socio- economic development of society.

Copyright (C) 2019 by author(s) and International Journal of Trend in Scientific Research and Development

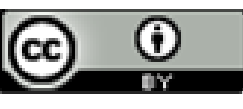
Journal. This is an Open Access article distributed under the terms of the Creative Commons Attribution License (CC BY 4.0) (http://creativecommons.org/licenses/by/4.0) 